\title{
An Empirical Investigation of the Relationship between Financial Development and Merchandise Trade in Nigeria
}

\author{
Oluwafemi Mathew Adeboje ${ }^{* *}$ \\ Isiaka Akande Raifu* \\ Frank I. Ogbeide \\ Olusegun Abiola Orija*
}

\begin{abstract}
This study examines the empirical relationship between financial development and merchandise trade in Nigeria using annual data from 1981 to 2014. The empirical analysis is also carried out on the disaggregated components of the trade, that is, merchandise export and import, for robust analysis. Estimation results based on error correction model show that there exists significant long run positive relationship between financial development and export in Nigeria over the period under study. There is need for government to therefore provide enabling environment for financial sector to thrive through sound macroeconomic policies for effective economic diversification through export.
\end{abstract}

Keywords: Error correction model; merchandise trade; financial development

JEL classification: $\mathrm{C} 22, \mathrm{~F} 49, \mathrm{G} 28$

\section{Introduction}

In the early day of economic activities, transactions were done in crude manners; however, as society becomes complex, economic activities, especially trading, become more sophisticated. This necessitates the emergence of financial institutions as a third party that will ensure smooth transactions between two or more trading partners. Since then financial institutions have played an intermediary role in the econo-

\footnotetext{
† Oluwafemi Mathew Adeboje is at the Research, Policy \& International Relations Department, Nigeria Deposit Insurance Corporation, Abuja.

${ }^{\dagger}$ Frank I. Ogbeide, Ph.D. is a Principal Economist in the Research, Policy \& International Relations Department, Nigeria Deposit Insurance Corporation, Abuja.

* Oluwafemi Mathew Adeboje, Isiaka Akande Raifu and Olusegun Abiola Orija are at the Department of Economics, Faculty of Economics and Management Sciences, University of Ibadan.
} 
my and through their intermediary role, they have been adjudged to have significant effects on the development of many nations (Schumpeter, 1912 and 1933).

In this twenty-first century and as the world becomes globalised, there have been a development of integration of not only the world economy but also its financial system thus, the functions of financial system are not limited to aiding the domestic economy alone but facilitating the world transactions, particularly between the importers and exporters. Since importers and exporters need some forms of trading payment and financing mechanisms, the role of financial institutions, particularly banks, becomes paramount important in international transactions. Of all the financial institutions, banks play a crucial role in international transaction by facilitating or ensuring payment to exporters and the delivery of goods and services to importers. Facilitating the international transactions is not limited to banks alone, other components of financial institutions such as equity markets, bond markets, foreign exchange markets as well as derivative markets are also indispensable in international transactions.

The importance of financial development in international transaction was brought to fore during the 2008-2009 global financial crisis as the world economy depressed considerably, particularly development economies, including African countries. For instance, according to World Trade Organisation (WTO), the volume of world trade fell by $12 \%$ in 2009 with varying degrees of severity across continents. Specifically, in North America, the volume of merchandise export fell by 15\%, Europe 15\%, South America 8\%, and Asia 11\%. Baldwin (2009) summarises the effect of 2007-2009 financial crisis on the volume of exports in both developed and developed countries. According to him, the volume of exported goods and services fell by $11.2 \%$ in advanced economies and by $7.6 \%$ in emerging and developing economies. Sub-Saharan African countries were not left out. Using Nigeria as an example, the volume of imports in 2009 fell by $2.0 \%$, exports fell by $17.1 \%$ and total trade fell by $11.9 \%$. During the same period, loans advances to exports fell by $39.0 \%$ while the stock market indicators such as market capitalisation and all share index fell by $26.5 \%$ and $33.8 \%$ respectively (CBN statistical bulletin, 2014).

In a bid to examine the importance of financial development on international transactions, several theoretical and empirical studies have been carried out, particularly in advanced countries. Theoretical foundation on this subject matter was laid by Kletzer and Bardhan (1987). Their study shows financial sector may be the source of comparative advantagein international trade. In other words, they assume that if countries have the same technology or resources, comparative advantage may differ in international trade due to the presence of credit market imperfections. Their theoretical work has been followed by several empirical studies, albeit with a mixed results (Svaleryd and Vlachos, 2002; Beck, 2002; Melina et al., 2004 and Keindrebeogo, 2012). Apart the facts the empirical results from these studies are mixed most of the studies are based on the cross-country with few country specific studies (Bojanic, 2012, Leibovici, 2013). Besides, considerable numbers of empirical studies have examined the reverse causation between financial development and international trade. 
The argument is that whether trade liberalisation promotes financial sector development (Huang and Temple, 2005; Do and Levchenko, 2007; Baltagi et al., 2009).

However, despite the large volume of theoretical and empirical literature on the relationship between financial development and international trade in cross-county studies and some other countries' specific studies, there are dearth of such studies in Nigeria. Most of the studies on the financial development focus on the relationship between financial development and economic growth. Recent studies on this include Kehinde and Adejuwon, (2011); Chinaemerem and Chigbu, (2012); Shittu, (2012); Nkoro and Uko, (2013); Oriavwote and Eshnake, (2014); Ogwumike and Salisu (2010).The empirical study that is closed to the issue of financial development and trade is done by Oluitan (2012). However, she does not address the effect of financial development on merchandise trade but rather considers the effect of trade components on financial development. Thus, the preoccupation of this study is to fill this noted gaped in the literature with the following questions being raised. To what extent is the development in financial sector affects merchandise trade in Nigeria? What impacts do the financial development variables have on the merchandise trade? What are the magnitudes of this effect? Besides, is there any long run relationship between financial development and trade in Nigeria? If there is shock in the financial sector, how long will it take for the trade and by extension economic to revert back to the long run equilibrium?

To address these questions, we employed error correction model (ECM) technique to address the issue of short run adjustment towards the long run equilibrium in case of shocks. However, we first determine the stationarity properties of our data using both Augmented Dickey Fuller and Phillip-Perron unit root tests. This is done to avoid spurious regression in our analysis. Thereafter, we also used Johansen Cointegration technique to determine whether our variables of interest are cointegrated, that is, if they have a long run relationship and later employed baseline regression technique (Ordinary Least Square) to examine the effect of financial development on the components of merchandise trade in Nigeria. Several post estimation techniques (Diagnostic tests) auch as Jacque-Bera (Normality test), Serial Correlation LM test, ARCH heteroscedasticity test and Ramsey Resest (Linearity test) were performed to validate our results

Our results show that our variables of interest became stationary after first difference and they are cointegrated. Besides, we also find that financial development has positive effects on the overall merchandise trade and merchandise exports, albeit it is statistically significant in the case of merchandise exports. Also, there is short run adjustment towards the long run equilibrium and that all our models passed our models all the aforementioned diagnostic tests.

The rest of the study is organized as follows: the next Section provides an overview of the financial development and merchandise trade in Nigeria, Section three gives a review of empirical literature on the subject, while data sources and description methodology and empirical results are presented in section four. Finally, conclusion and policy recommendations are provided in section five. 


\section{An Overview of Financial Development and Merchandise Trade in Nigeria}

This section of the study provides background information on the state of financial development and merchandise trade in Nigeria. This is achieved by examining the historical patterns of the domestic credit to private sector and money and quasi money to understand the extent of financial development, as well as the pattern of trade variables which includes export, import and trade openness.

Table 1 provides the needed information on the economic variable of interest from 1960 to 2014. For a clearly information, the sample size was averaged over the period of five years. Taking financial development variables first, domestic credit to private sector as \% of GDP was observed to be less than $30 \%$ over the last five decade. This point out clearly that financial development is still low in the country despite various financial reforms introduced in the country. However, the value shows that there exist some period of improvement in the financial institution in the country. For instance, prior to the period Structural Adjustment Programme (hereafter SAP) was introduced, the ratio of domestic credit to private sector to GDP was found to be increasing in value from 5.15\% in 1960-1964 to an average of 15.79\% in 1980-1984.

The ratio was found to decline post financial liberalization of 1986, the ratio follows a declining pattern up till 2000-2004, when it cease to decline. The period when the ratio began to rise coincide to the period when universal banking was introduced. The policy to an extent boosts credit creation in the country relatively to the rate of growth of the economy. Also, the increment in the bank's capital based also push the ratio upward by a multiple of two. The financial crises in 2008/2009 crippled into the Nigeria financial institution due to financial integration bring down to ratio to a rate lower than its level prior to increase in capital base.

The pattern observed in the movement of the other measure of financial development, money and quasi as \% of GDP follows similar pattern the movement of domestic credit to private sector as \% of GDP. The only difference is the period in which the peak value is obtained, the peak value for domestic credit to private sector as $\%$ of GDP occurred between the periods of 2005-2009 while that of money and quasi money as \% of GDP occurred between the periods of 1980-1984.

In terms of trade movement, we examined the pattern of movement for exports of goods and services as \% of GDP, imports of goods and services as \% of GDP and trade openness. The study of the above named economic variables trend is to provide insights on the effect of trade policy on Nigeria trade pattern. As depicted in Table 1, prior to the liberalization of the Nigeria foreign trade in 1986 through exchange rate policy and the relaxation of trade barriers in terms of tariff and custom duties, export to GDP was low, it was found to be less than $22 \%$. Though on the upward path until $1980-1984$ when it fell from $21.16 \%$ recorded in 1975-1979 to 19.93 in 1980-1984. The observed decline is as a result of global decline in the demand for crude oil which constitutes more than $75 \%$ of our export composition then. As the global oil 
demand improves as well as the depreciation of the exchange rate, export to GDP rose to 34.54 in the succeeding period. The upward trend in export as a \% of GDP was sustained up till 2000-2004 when its value was found to be twice that of 1980-1984. Though since then, the value of export as \% of GDP had been declining, majorly due to reduction in oil export and non-competitive nature of our agricultural export.

The trend of import as \% of GDP follows a fluctuating patterns, it is less predictive like export as \% of GDP. Some notable features could be deduced from the trend. For instance, the ratio of import to GDP was found to increase during the period in which oil revenue was rising 1970-1979 and 1990-2000. It was found to decline during the period oil revenue was declining as well 1980-1984. Depreciation of exchange rate that accompanied exchange rate liberalization was found to hurt import as it increased the cost of importation.

Lastly, trade openness which suggest how opened an economy is to international trade, which is measured as the sum of export and import divided by GDP. The trend of trade openness to a large extent follows that of export as a \% of GDP. It implies that the overall trade activities in the country is influenced by export movement, the extent of export determined how opened the economy will be. The average value of trade openness pre SAP was found to be less than what was obtainable after post SAP. Trade flows increased after SAP. This can be attributed to the commitment of world trade organization to reduce trade barriers as possible. Though, drop in economic activities after financial crises of 2008/2009 and the decline in world aggregate demand as resulted into decline in trade openness in 2010-2014, with a value $40.21 \%$, this is found to be its lowest since the last 25 years.

Table 1: Historical Information on the Study Key variables

\begin{tabular}{|l|c|c|c|c|c|}
\hline & $\begin{array}{c}\text { Domestic credit } \\
\text { to private sector } \\
\text { (\% of GDP) }\end{array}$ & $\begin{array}{c}\text { Money and quasi } \\
\text { money (M2) as } \\
\text { \% of GDP }\end{array}$ & $\begin{array}{c}\text { Exports of goods } \\
\text { and services } \\
\text { (\% of GDP) }\end{array}$ & $\begin{array}{c}\text { Imports of goods } \\
\text { and services } \\
\text { (\% of GDP) }\end{array}$ & $\begin{array}{c}\text { Trade } \\
\text { (\% of GDP) }\end{array}$ \\
\hline $1960-1964$ & 5.15 & 9.75 & 8.94 & 15.15 & 24.08 \\
\hline $1965-1969$ & 7.25 & 12.57 & 10.74 & 15.84 & 26.58 \\
\hline $1970-1974$ & 5.44 & 11.26 & 14.26 & 13.31 & 27.57 \\
\hline $1975-1979$ & 9.01 & 20.84 & 21.16 & 22.42 & 43.58 \\
\hline $1980-1984$ & 15.79 & 31.01 & 19.93 & 17.12 & 37.05 \\
\hline $1985-1989$ & 14.42 & 26.75 & 24.90 & 12.50 & 37.39 \\
\hline $1990-1994$ & 11.78 & 24.74 & 34.54 & 21.33 & 55.87 \\
\hline $1995-1999$ & 11.25 & 16.73 & 34.67 & 28.60 & 63.27 \\
\hline $2000-2004$ & 13.78 & 21.78 & 40.62 & 27.43 & 68.05 \\
\hline $2005-2009$ & 24.76 & 29.17 & 35.83 & 25.49 & 61.32 \\
\hline $2010-2014$ & 13.38 & 20.90 & 24.43 & 15.78 & 40.21 \\
\hline
\end{tabular}

Source: Computed by Authors from the World Development Indicator Database, (2015) 


\section{Literature Review}

This section reviews briefly the empirical studies on the relationship between financial development, trade and economic growth and vice versa. The importance of financial development in the course of economic growth has been well documented in both theoretical and empirical studies. Early studies in this regard include Schumpeter (1911, 1933), Goldsmith (1955, 1969, Gulley and Shaw (1960), Gerschenkron (1962), Mckinnon (1973) and Shaw (1973). In recent time, we have King and Levin, (1993), Rajan and Zingale (1998), Beck and Levin (2004) and Caporale et al., (2009). The results from these studies agree that financial development exert positive impact on the economic growth.

The studies on the financial development-economic growth nexus are not limited to advanced countries only but also there are considerable studies on the subject matter in the developing countries, particularly in Nigeria and some other developing countries (see Kehinde and Adejuwon, 2011; Chinaemerem and Chigbu, 2012; Shittu, 2012; Nkoro and Uko, 2013; Oriavwote and Eshnake, 2014; Ogwumike and Salisu (2010); Fantessi, 2015).

Empirical works that directly connect the financial development and trade together can be broadly grouped into two. First, there are some studies that focus on how financial development drives international trade either at micro or macro levels. The second strands of literature, however, reverse this relationship. Specifically, the second strands of literature focus on how trade or trade openness affects or drives financial development.

Beginning from the first strands of literature, Do and Levchenko (2004) work on trade and financial development, using the panel data of 77 countries comprising 22 OECD countries and 55 developing countries and covering a period from 1965 to 1995 , found that trade openness is conditioned on faster financial development in wealthier countries and on slower financial development in developing countries. In other words, their results show that wealthier countries with well-developed financial sector enjoy higher trading cum trade openness than developing countries with slow financial development.

Corroborating Do and Levchenko findings, Chan and Manova (2015), working on financial development and the choice of trading partners in 78 exporting countries and 27 industries and covering a period of 1985-1995, found that financial development positively determines exporter's destination counts, however, with pecking order destinations conditioned on the country's market size and trading costs. In other words, financially developed countries do have many trading partners.

On the issue of the nature or the direction of causality between financial development, and trade, several studies have found that financial development and international trade do have bidirectional relationship; Keindrebeogo (2012) found that bidirectional relationship exists between the level of financial development and inter- 
national trade. He, however, noted that there is a little effect of financial development on economic international trade. Besides, his empirical results show that financial development contributes to this causal relationship in developing countries than in developed countries. Pham (2010) also found similar result to Keindrebeogo. In his work on financial development, financial openness and trade openness, he discovered that trade openness and financial development have bidirectional relationship or causality and that financial openness is heterogeneous across difference measures and that the inclusion of financial openness does change the nature of relationship between financial development and trade openness.

Apart from the issues of causality, the research has focused on the impact of financial crisis on the international trade to buttress the importance of financial development on international trade. The corporate results show that financial crisis does reduce international trade. In other words, during the financial crisis, trade volume always declines. For instance, Berman (2007) works on financial crisis and international trade: the long way to recovery using 10,000 firms in 80 countries covering a period of 1975-2003, found that financial crisis has a long-lasting negative effect on trade flows. In specific terms, financial crisis has negative and persistent effect such as currency crisis on exports which is due to negative balance sheets.

Leibovici (2013) found the similar results to Berman. While working on financial development and international with focus on Chile's firms, Leibovici found that financial frictions reduce the international trade with varying degree of impact across industries and based on the access to external finance. However, there is a negligible effect of financial frictions on international trade at aggregate level. Thus, industries with limited access to finance, particularly external finance, do have a lower trade share compared with other industries with access to external finance.

The foregoing literature review shows that the dust surrounding financial development-international trade nexus or international trade-financial development nexus remains unsettled. In fact, the review reveals dichotomy in the role of financial development and international trade and vice versa between developed countries and developing countries. Besides, since most of the studies even focus on the cross-country investigation or employment of panel data in carrying out their analyses, the level of individual country's financial development may not be well accounted for and the effect on the trade of the country may be ascertained. This calls for country's specific studies, both at aggregate level and micro level, on the effect of financial development on international trade and vice versa so as to formulate necessary policies for financial development and trading activities, home and abroad. 


\section{Data, Methodology and Discussion of Empirical Results}

\section{Data}

The study made use of annual data covering the period from 1981 to 2014. The data were basically sourced from two databases-World Development Indicators (WDI) and Central Bank of Nigeria (CBN).The variables used include credit provided by the financial sector scaled by GDP, merchandise import, merchandise export, total merchandise trade, real exchange rate, real GDP, investment proxied by gross fixed capital formation, government consumption expenditure, external reserves, foreign direct investment (FDI) and industrial production.

\section{Methodological Approach}

To examine the short-run and long-run relationship between financial development and merchandise trade, error correction model is applied. Three types of models were specified which include merchandise import model, merchandise export model and total merchandise trade model. In each of the model, the variables included, apart from the financial development variable which is constant or consistent in all the models, are based on the basis of a priori factors that have adjudged to determine any of dependent variable, be it merchandise import, merchandise export or total merchandise trade. For instance, with regard to merchandise import model, existing studies such as Abdullahi and Suleiman, (2008) and Aker, (2008) showed that variables such as real GDP which serves as income of an importing country, real exchange rate (measured in terms of domestic currency per unit of foreign currency), gross fixed capital formation a proxy for the level of investment in importing country, foreign reserves which determines the ability of importing country to pay are the factors that determine the amount of import of goods and services made by a country. This informs the rationale for including these variables in our model of merchandise import and financial development relationship. On the determinants of export, factors such as foreign direct investment, domestic investment, real exchange rate, income from the rest of the world usually proxied by real world GDP among others are the factors determining the volume of export of a country (Majeed and Ahmad, 2006; Beoy, 2010; Yee, et al, 2016). In the case of model for total trade, GDP and Industrial Production represent different things. While GDP denotes the aggregate economic performance comprising the outputs of different sectors of the economy, the industrial production simply represents the output of manufacturing sectors activity at industrial level. The goal is to see their impact on the trade performance in Nigeria. 
The long-run specification of the merchandise import model is presented as:

$$
\begin{aligned}
\ln (M I M P)= & \alpha_{0}+\alpha_{1} \ln (C B F S)+\alpha_{2} \ln (R E X R)+\alpha_{3} \ln (R G D P)+ \\
& \alpha_{4} \ln (I N V E S)+\alpha_{5} \ln (G C E)+\alpha_{6} \ln (E X R E S)+\varepsilon_{t}
\end{aligned}
$$

However, the short-run dynamics specification of the merchandise import model is presented as:

$$
\begin{aligned}
\Delta \ln (M I M P)= & \beta_{0}+\beta_{1} \ln (C B F S)+\sum_{i=1}^{m} \beta_{2} \Delta \ln (M I M P)_{t-1}+\sum_{i=0}^{n} \beta_{3} \Delta \ln (X)_{t-1}+ \\
& \delta E C M_{t-1}+\varepsilon_{t}
\end{aligned}
$$

For the merchandise export model, the long-run model is specified as:

$$
\begin{gathered}
\ln (M E X P)=\alpha_{0}+\alpha_{1} \ln (C B F S)+\alpha_{2} \ln (R E X R)+\alpha_{3} \ln (I N D U)+\alpha_{4} \ln (F D I)+ \\
\alpha_{5} \ln (G C E)+\alpha_{6} \ln (R G D P R W)+\varepsilon_{t}
\end{gathered}
$$

While the short-run dynamics specification of the merchandise export model is specified as:

$$
\begin{aligned}
\Delta \ln (M E X P)= & \beta_{0}+\beta_{1} \ln (C B F S)+\sum_{i=1}^{m} \beta_{2} \Delta \ln (M E X P)_{t-1}+\sum_{i=0}^{n} \beta_{3} \Delta \ln (X)_{t-1}+ \\
& \delta E C M_{t-1}+\varepsilon_{t}
\end{aligned}
$$

Furthermore, the overall long-run model specification for the total merchandise trade is:

$$
\begin{aligned}
\ln (M I T)= & \alpha_{0}+\alpha_{1} \ln (C B F S)+\alpha_{2} \ln (R E X R)+\alpha_{3} \ln (R G D P)+\alpha_{4} \ln (I N D U)+ \\
& \alpha_{5} \ln (F D I)+\varepsilon_{t}
\end{aligned}
$$

The short run dynamics model specification for the total merchandise trade is:

$$
\begin{aligned}
\Delta \ln (M I T)= & \beta_{0}+\beta_{1} \ln (C B F S)+\sum_{i=1}^{m} \beta_{2} \Delta \ln (M I T)_{t-1}+\sum_{i=0}^{n} \beta_{3} \Delta \ln (X)_{t-1}+ \\
& \delta E C M_{t-1}+\varepsilon_{t}
\end{aligned}
$$

Where:

$\ln (M I M P)$ is natural logarithm of merchandise import

$\ln (M E X P)$ is for natural logarithm of merchandise export

$\ln (M I T)$ is natural logarithm of total merchandise trade

$\ln (C B F S)$ is natural logarithm of credit provided by financial sector, a proxy for financial development

$\ln (R E X R)$ is natural logarithm of real exchange rate

$\ln (R G D P)$ is natural logarithm of real GDP

$\ln (I N V E S)$ is natural logarithm of investment 
$\ln (G C E)$ is log natural logarithm of government consumption expenditure $\ln (E X R E S)$ is natural logarithm of external reserves

$\ln (F D I)$ is natural logarithm of foreign direct investment $\ln (R G D P R W)$ is natural logarithm of real GDR for the rest of the world $\ln (I N D U)$ is natural logarithm of industrial production index $\ln (X)_{t-1}$ is natural logarithm of lags of independent variable

$E C M$ denotes error correction variable. It is residual obtained from the estimation of long run model and included in the short run estimation model.

$\alpha$ 's and $\beta$ 's are coefficient parameters of the independent variables

$\delta$ is the coefficient parameter of error correction variable and its sign and level of significant level as well as its value determine the speed of adjustment from short-run towards long-run equilibrium.

\section{Presentation of Empirical Results}

Correlation between Trade and Financial Development

In table 3, the correlation matrix results based on the considered three models are presented. The results show that credit provided by financial institutions to private sector exhibit a positive and significant association with merchant imports and exports respectively, however, it is negatively and significantly related to overall merchandise trade scaled by GDP. In specific terms, the correlation coefficients of credit with merchandise imports, exports and total merchant trade are $0.7135(\mathrm{p}<0.05)$, $0.6148(\mathrm{p}<0.05)$ and $(0.5518)(\mathrm{p}<0.05)$ respectively. Other control variables, however, exhibits different correlation with imports, exports and overall trade based on the model specifications. For instance, while industrial production index is negatively and significantly correlated with exports, it is, however, positively and significantly associated with total trade. Also, real GDP, investment, government consumption expenditure as well as external reserves are all positively and significantly correlated with merchandise import. While foreign direct investment has a negative and significant association with merchant export, it, however, exhibits positive correlation with merchant trade, albeit, not statistically significant. We can also observe from the table that real exchange rate has negative insignificant correlation with merchandise import and merchandise export, while exhibiting positive insignificant correlation with overall merchandise trade. 
Table 3: Correlation Matrix of the Variables

\begin{tabular}{|c|c|c|c|c|c|c|c|}
\hline \multicolumn{8}{|c|}{ MERCHANDISE IMPORT MODEL } \\
\hline Variable & LIMP & LCBFS & LREXR & LGDPR & LINVES & LGCE & LEXRES \\
\hline LIMP & 1.000 & & & & & & \\
\hline LCBFS & $0.713 * * *$ & 1.000 & & & & & \\
\hline LREXR & -0.02 & 0.153 & 1.000 & & & & \\
\hline LGDPR & $0.901 * * *$ & $0.638 * * *$ & -0.286 & 1.000 & & & \\
\hline LINVES & $0.867 * * *$ & $0.749 * * *$ & 0.134 & $0.684 * * *$ & 1.000 & & \\
\hline LGCE & $0.883 * * *$ & $0.696 * * *$ & -0.246 & $0.963 * * *$ & $0.678 * * *$ & 1.000 & \\
\hline LEXRES & $0.647 * * *$ & $0.436 * *$ & $-0.477 * * *$ & $0.846^{* * * *}$ & $0.397 *$ & $0.828 * * *$ & 1.000 \\
\hline \multicolumn{8}{|c|}{ MERCHADISE EXPORT MODEL } \\
\hline & LMEXP & LCBFS & LREXR & LINDU & LFDI & RGDPRW & \\
\hline LMEXP & 1.000 & & & & & & \\
\hline LCBFS & $0.614 * * *$ & 1.000 & & & & & \\
\hline LREXR & -0.225 & 0.152 & 1.000 & & & & \\
\hline LINDU & $-0.372 * *$ & $-0.719 * * *$ & $-0.305^{*}$ & 1.000 & & & \\
\hline LFDI & -0.087 & $-0.337 *$ & $-0.524 * * *$ & $0.537 * * *$ & 1.000 & & \\
\hline RGDPRW & $0.817 * * *$ & $0.349 * *$ & $-0.539 * * *$ & -0.190 & 0.266 & 1.000 & \\
\hline \multicolumn{8}{|c|}{ MERCHANDISE TRADE MODEL } \\
\hline & LMTT & LCBFS & LREXR & LGDPR & LINDU & LFDI & \\
\hline LMTT & 1.0000 & & & & & & \\
\hline LCBFS & $-0.551 * * *$ & 1.000 & & & & & \\
\hline LREXR & 0.029 & 0.152 & 1.0000 & & & & \\
\hline LGDPR & $-0.599 * * *$ & $0.652 * * *$ & -0.264 & 1.000 & & & \\
\hline LINDU & $0.724 * * *$ & $-0.719 * * *$ & $-0.305^{*}$ & $-0.454 * * *$ & 1.000 & & \\
\hline LFDI & 0.501 & $-0.337 *$ & $-0.524 * * *$ & -0.054 & $0.537 * * *$ & 1.000 & \\
\hline
\end{tabular}

Source: Authors' computation using EVIEWS software

Note: $* * *, * *$ and $*$ represent $1 \%, 5 \%$ and $10 \%$ level of significance respectively.

\section{Unit Root Test Results}

To examine the properties of the data series, both Augmented Dickey-Fuller and Philip-Perron methods of unit root test are employed. The results from the table 4, therefore, show that all variables are not stationary at level. They are, however, made stationary after they are first differenced. In other words, they are integrated of order I(1). Having known the order of integration of the variables, the next is to determine whether the variables are cointegrated. 
Table 4: Unit Root Test Results

\begin{tabular}{|l|c|c|c|c|c|}
\hline & \multicolumn{2}{|c|}{ Augmented Dickey-Fuller (Constant) } & \multicolumn{2}{|c|}{ Phillip-Perron (Constant) } & \\
\hline Variable & Level & First Difference & Level & First Difference & Decision \\
\hline LMTT & -1.393 & $-6.403^{* * *}$ & -1.323 & $-6.718^{* * *}$ & $\mathrm{I}(1)$ \\
\hline LMEXP & -0.202 & $-4.972^{* * *}$ & 0.010 & $-6.255^{* * *}$ & $\mathrm{I}(1)$ \\
\hline LMIMP & -0.119 & $-5.486^{* * *}$ & -0.459 & $-5.506^{* * *}$ & $\mathrm{I}(1)$ \\
\hline LCBFS & -1.262 & $-4.530^{* * *}$ & -1.449 & $-4.427 * * *$ & $\mathrm{I}(1)$ \\
\hline LRGDP & 1.761 & $-4.248^{* * *}$ & 1.761 & $-4.233^{* * *}$ & $\mathrm{I}(1)$ \\
\hline LRGDPRW & -1.584 & $-4.751^{* * *}$ & -2.029 & $-4.776^{* * *}$ & $\mathrm{I}(1)$ \\
\hline LINDU & -0.714 & $-5.638^{* * *}$ & -1.687 & $-6.345^{* * *}$ & $\mathrm{I}(1)$ \\
\hline LREXR & -2.024 & $-4.252^{* * *}$ & -2.207 & $-4.159 * * *$ & $\mathrm{I}(1)$ \\
\hline LEXRES & -1.382 & $-6.896^{* * *}$ & -1.382 & $-6.924 * * *$ & $\mathrm{I}(1)$ \\
\hline LINVES & -1.546 & $-4.434^{* * *}$ & -1.956 & $-4.457 * * *$ & $\mathrm{I}(1)$ \\
\hline LFDI & $-2.751 *$ & $-9.657^{* * *}$ & -2.592 & $-9.808^{* * *}$ & $\mathrm{I}(1)$ \\
\hline LGCE & 0.192 & $-3.397 * *$ & 0.081 & $-5.966^{* * *}$ & $\mathrm{I}(1)$ \\
\hline
\end{tabular}

Source: Authors' computation using EVIEWS software

Note: $* * *, * *$ and $*$ represent $1 \%, 5 \%$ and $10 \%$ level of significance respectively.

Johansen Cointegration Test Results

The cointegration tests are done to determine whether our variables of interest are cointegrated or not, that is, whether they have a long-run relationship. Since the cointegration tests are sensitive to lag selection criteria, the maximum lag length selected is two for the three models. From the table 5, we can observe that in all the model specifications, the variables are cointegrated, however, with varying degrees of cointegration. Precisely, in the merchandise trade model the trace test reports two cointegrating equations, while the maximum Eigen value test reports one cointegrating equation. Similarly, trace test records two cointegrating equation while the maximum Eigen value reports one cointegrating equation in the merchandise export model. However, in the merchandise import model, there are six cointegrating equations reported in trace test while three cointegrating equations were reported in maximum Eigen value test. The overall results, therefore, show that the variables of interest are cointegrated at 5\% level of significance which implies that there exists a long run relationship among the variables in each of the model. The next is to proceed to the estimation of long-run and short-run dynamic models. 
Table 5: Johansen Cointegration Test Results

\begin{tabular}{|c|c|c|c|c|c|c|c|}
\hline \multirow{2}{*}{$\begin{array}{c}\text { Trace Test } \\
\text { Ho }\end{array}$} & \multicolumn{3}{|l|}{$\mathbf{k}=\mathbf{2}$} & \multicolumn{4}{|c|}{ Maximum Eigenvalues Test $\quad k=2$} \\
\hline & $\mathbf{H}_{\mathrm{A}}$ & $(\lambda$ trace $)$ & $\begin{array}{c}\text { Critical } \\
\text { values }(5 \%)\end{array}$ & Ho & $\mathbf{H}_{\mathrm{A}}$ & $(\lambda$ Max $)$ & $\begin{array}{c}\text { Critical } \\
\text { values }(5 \%)\end{array}$ \\
\hline \multicolumn{8}{|c|}{ MERCHANDISE TRADE MODEL } \\
\hline $\mathrm{r} \leq 0$ & $r>0$ & $150.460 *$ & 95.754 & $r \leq 0$ & $r>0$ & $74.219^{*}$ & 40.078 \\
\hline $\mathrm{r} \leq 1$ & $\mathrm{r}>1$ & $76.241 *$ & 69.819 & $\mathrm{r} \leq 1$ & $\mathrm{r}>1$ & 30.514 & 33.877 \\
\hline $\mathrm{r} \leq 2$ & $\mathrm{r}>2$ & 45.728 & 47.856 & $r \leq 2$ & $r>2$ & 19.564 & 27.584 \\
\hline $\mathrm{r} \leq 3$ & $\mathrm{r}>3$ & 26.164 & 29.797 & $\mathrm{r} \leq 3$ & $\mathrm{r}>3$ & 15.063 & 21.132 \\
\hline $\mathrm{r} \leq 4$ & $r>4$ & 11.101 & 15.495 & $r \leq 4$ & $r>4$ & 10.891 & 14.265 \\
\hline $\mathrm{r} \leq 5$ & $r>5$ & 0.210 & 3.841 & $r \leq 5$ & $r>5$ & 0.210 & 3.841 \\
\hline \multicolumn{8}{|c|}{ MERCHANDISE EXPORT MODEL } \\
\hline$r \leq 0$ & $r>0$ & $154.765^{*}$ & 95.754 & $r \leq 0$ & $r>0$ & $76.093 *$ & 40.078 \\
\hline $\mathrm{r} \leq 1$ & $r>1$ & $78.671 *$ & 69.819 & $r \leq 1$ & $r>1$ & 33.070 & 33.877 \\
\hline$r \leq 2$ & $r>2$ & 45.601 & 47.856 & $r \leq 2$ & $r>2$ & 26.982 & 27.584 \\
\hline$r \leq 3$ & $r>3$ & 18.619 & 29.797 & $r \leq 3$ & $r>3$ & 12.628 & 21.132 \\
\hline$r \leq 4$ & $r>4$ & 5.990 & 15.495 & $r \leq 4$ & $r>4$ & 5.837 & 14.265 \\
\hline $\mathrm{r} \leq 5$ & $r>5$ & 0.153 & 3.841 & $r \leq 5$ & $r>5$ & 0.153 & 3.841 \\
\hline \multicolumn{8}{|c|}{ MERCHANDISE IMPORT MODEL } \\
\hline$r \leq 0$ & $\mathrm{r}>0$ & $209.84 *$ & 125.615 & $r \leq 0$ & $r>0$ & $69.21 *$ & 46.231 \\
\hline $\mathrm{r} \leq 1$ & $r>1$ & $140.63 *$ & 95.754 & $\mathrm{r} \leq 1$ & $\mathrm{r}>1$ & $54.20 *$ & 40.078 \\
\hline $\mathrm{r} \leq 2$ & $\mathrm{r}>2$ & $86.42 *$ & 69.819 & $\mathrm{r} \leq 2$ & $r>2$ & $35.48 *$ & 33.877 \\
\hline $\mathrm{r} \leq 3$ & $r>3$ & $50.95^{*}$ & 47.856 & $r \leq 3$ & $r>3$ & 26.31 & 27.584 \\
\hline$r \leq 4$ & $r>4$ & 24.63 & 29.797 & $r \leq 4$ & $r>4$ & 17.26 & 21.132 \\
\hline $\mathrm{r} \leq 5$ & $\mathrm{r}>5$ & 7.38 & 15.495 & $r \leq 5$ & $r>5$ & 7.10 & 14.265 \\
\hline$r \leq 6$ & $r>6$ & 0.27 & 3.841 & $r \leq 6$ & $r>6$ & 0.27 & 3.841 \\
\hline
\end{tabular}

Source: Authors' computation using EViews software

Note: * represents the number of cointegrating equations in both trace and maximum eigen value tests

The Results of Long-run Relationship between Financial Development and Trade

Having discovered that the variables are cointegrated, the next is to carry out the long run estimation for all the models. Thus, table 6 presents the long run form results for all the three models. Beginning with the overall significance of the models, the $\mathrm{R}^{2}(\mathrm{~s})$, which depict the explanatory power of the all variables included in all the estimations, show that all the models are statistically fit. To be precise, the $\mathrm{R}^{2}(\mathrm{~s})$ of the 0.731 , 0.845 and 0.943 show that $73.1 \% .84 .5 \%$ and $94.3 \%$ of the variation in the dependent variables are explained by the combination of all the independent variables included in the estimations while the rest percents are due to all the variables not included in 
the estimation. This is corroborated by F-statistic tests which are statistically significant at 5\% level of significance in all the models.

The financial institution to private sector has positive effect on merchandise trade, albeit not statistically significant. In the merchandise export model, the credit exhibits positive and significant effect on merchandise exports. Specifically, one percent increase in the credit provided by financial institution will lead to 0.937 percent in merchandise export, holding other variables constant. However, in the merchandise import model, the credit is negatively and insignificantly related to merchandise import. Other variables included in the models exhibit diverse effects on the overall merchandise trade, export and import. For instance, real exchange rate, FDI and industrial production index have positive and significant effect on merchandise trade; however, real GDP exhibits an unexpected sign in the merchandise trade as it is negatively and significantly related with trade. This is, however, not surprised considering the country's largest trading commodity (crude oil) which contributes less to the make-up of GDP computation. Worthy of consideration is the effect of the rest of the world GDP on merchandise export. Specifically, the foreign GDP has a positive and significant effect on trade. In terms of magnitude, a one percent increase in the rest of the world GDP will stimulate merchandise export by $5.61 \%$, holding other variables constant. Similarly, industrial production index also has positive and significant on trade. FDI, however, reduces merchandise export as it exhibits negative and significant impact on it. In the merchandise import, real exchange rate and industrial production index as well as investment are all positive significant effect on merchandise import. Some of these results seem implausible; however, considering the nature of economy in which this study is carried out will attenuate the implausibility of the results. For instance, a positive effect of industrial production index may stem from the fact that most of the locally produced goods are not patronised like foreign goods. This has led to the moribund industrial sector in the country with little or no contribution to the GDP. 
Table 6: Long run Model Results

\begin{tabular}{|c|c|c|c|}
\hline Variable & LMTT MODEL & MEXP MODEL & MIMP MODEL \\
\hline Constant & $7.543^{* *}$ & $-30.831 * * *$ & $-33.193 * * *$ \\
\hline LCBFS & 0.138 & $0.937 * * *$ & -0.190 \\
\hline LREXR & $0.123 * *$ & 0.172 & $0.131 *$ \\
\hline LRGDP & $-0.223 * *$ & & $1.114 * * *$ \\
\hline LINDU & $0.643^{* * *}$ & $0.872 *$ & \\
\hline LFDI & $0.160 * * *$ & $-0.339 * *$ & \\
\hline LRGDPRW & & $5.607 * * *$ & \\
\hline LINVES & & & $0.671 * * *$ \\
\hline LGCE & & & 0.110 \\
\hline LEXRES & & & -0.053 \\
\hline $\mathrm{R} 2$ & $0.731(73.10 \%)$ & $0.845(84.54 \%)$ & $0.943(94.31 \%)$ \\
\hline Adjusted R2 & $0.683(68.30 \%)$ & $0.817(1.78 \%)$ & $0.930(93.00 \%)$ \\
\hline F-Statistic & $15.219(0.000)$ & $30.632(0.000)$ & $71.81(0.000)$ \\
\hline
\end{tabular}

Source: Authors' computation using EViews software

Note: $* * *, * *$ and $*$ represent $1 \%, 5 \%$ and $10 \%$ level of significance respectively.

The Results of Short-run Relationship between Financial Development and Trade

The short run dynamic estimated results are presented in table 7. From the table, the coefficients of error correction terms in all the models are not only negative as predicted in the theory but also highly statistically significant at $1 \%$ level of significance. This shows that there is a short run dynamic adjustment towards the long run equilibrium. The magnitudes of the coefficients are quite higher which show a quick return to the long run equilibrium in case there is disequilibrium in the system. To be precise, the coefficients of error correction terms of $-0.915,-0.574$ and $-0.624 \%$ shows that $91.5 \%, 57.4 \%$ and $62.4 \%$ of the errors are corrected for in each of the model respectively and it takes less than two years for the adjustment towards the long-run equilibrium to occur from short run disequilibrium.

It can observed from the results that credit provided by the financial institution to the private sector is not important to trade activities in the short run all the models. Specifically, lagged real exchange rate, industrial production index, FDI are very germane to merchandise trade in the short run while lagged merchandise exports, real exchange rate, industrial production index as well as foreign GDP are major factors that determine merchandise export in the short run. A closer look at the table also reveals that lag of credit in second period reduces merchandise import. Likewise the lags of government consumption expenditure, real GDP ( $1^{\text {st }}$ period lag) and external reserves exert negative and significant effect on merchandise import. However, 
the lags of real GDP in second period and government consumption (without being lagged) have positive and significant effects on merchandise import.

Table 7: Short run Dynamic Model Results

\begin{tabular}{|c|c|c|c|}
\hline Variable & LMT MODEL & MEXP MODEL & MIMP MODEL \\
\hline Constant & -0.013 & $-2.925 *$ & -0.007 \\
\hline $\mathrm{D}(\mathrm{LCBFS})$ & $0.330 *$ & & \\
\hline $\mathrm{D}(\operatorname{LCBFS}(-1))$ & & & -0.206 \\
\hline $\mathrm{D}(\operatorname{LCBFS}(-2))$ & & & $-0.251 * *$ \\
\hline $\mathrm{D}(\operatorname{LMEXP}(-2))$ & & $0.130 * *$ & \\
\hline D(LREXR) & $0.148 *$ & $0.249 *$ & \\
\hline D(LMTT(-1)) & 0.259 & & \\
\hline $\mathrm{D}(\operatorname{LREXR}(-1))$ & & 0.177 & \\
\hline D(LRGDP) & & & $2.429 * * *$ \\
\hline D(LRGDP(-1)) & & & $-2.260 * *$ \\
\hline $\mathrm{D}(\operatorname{LRGDP}(-2))$ & & & $1.199 * * *$ \\
\hline $\mathrm{D}(\mathrm{LINDU})$ & $0.488 * *$ & $1.223 * * *$ & \\
\hline D(LINDU(-1)) & -0.125 & $0.565^{*}$ & \\
\hline D(LINDU(-2)) & -0.210 & & \\
\hline $\mathrm{D}(\mathrm{LFDI})$ & $0.163^{* * *} *$ & & \\
\hline $\mathrm{D}(\mathrm{LFDI}(-1))$ & & 0.075 & \\
\hline $\mathrm{D}(\mathrm{LFDI}(-2))$ & 0.067 & & \\
\hline D(LRGDPRW) & & $5.566^{*}$ & \\
\hline D(LRGDPRW(-1)) & & -5.043 & \\
\hline D(LRGDPRW(-2)) & & -5.512 & \\
\hline D(LINVES(-1)) & & & $0.545 * * *$ \\
\hline D(LGCE) & & & $-0.209 * *$ \\
\hline $\mathrm{D}(\mathrm{LGCE}(-1))$ & & & $0.485 * * *$ \\
\hline D(LEXRES) & & & $-0.112 * * *$ \\
\hline D(LEXRES(-2) & & & $-0.099 * *$ \\
\hline $\mathrm{ECT}(-1)$ & $-0.915^{* * *}$ & $-0.574 * * *$ & $-0.624 * * *$ \\
\hline $\mathrm{R} 2$ & $0.618(61.88 \%)$ & $0.668(66.88 \%)$ & $0.895(89.56 \%)$ \\
\hline Adjusted R2 & $0.455(45.54 \%)$ & $0.503(50.33 \%)$ & $0.831(83.18 \%)$ \\
\hline F-statistic & $3.787(0.005)$ & $4.039(0.003)$ & $14.038(0.000)$ \\
\hline Durbin-Watson & 1.89 & 2.03 & 2.17 \\
\hline
\end{tabular}

Source: Authors' computation using EViews software

Note: $* * *, * *$ and $*$ represent $1 \%, 5 \%$ and $10 \%$ level of significance respectively. 
Diagnostic Test

The validity of the results presented above in different sections under different model specifications depends on the satisfaction of the assumptions of classical ordinary least squares such as linearity, normality, homoscedasticity and no serial correlation assumptions to mention but a few. In other to validate these results, the following diagnostic tests were carried out, namely: normality test, serial correlation test, heteroscedasticity test as well as linearity test. Each test has its null hypothesis against which the alternative hypothesis is tested. For instance; the null hypothesis under normality test is that the model is normally distributed with zero mean and constant. The null hypotheses under serial correlation, heteroscedasticity and linearity tests are that no serial correlation, no heteroscedasticity and linearity in parameter respectively. The results of these tests are presented in table 8 . The results show that all the models pass the tests conducted as it is impossible to reject the null hypothesis in any of the model. This implies that the models are reliable and can be employed for economic policy formulation, forecasting and prediction.

Table 8: Post Estimation/Diagnostic Tests

\begin{tabular}{|l|c|c|c|}
\hline Test & LMTT MODEL & MEXP MODEL & MIMP MODEL \\
\hline Jacque-Bera & $0.627(0.730)$ & $4.407(0.110)$ & $0.837(0.658)$ \\
\hline Serial Correlation LM Test & $0.014(0.986)$ & $0.325(0.726)$ & $0.152(0.860)$ \\
\hline ARCH Heteroskedasticity Test & $2.111(0.157)$ & $0.361(0.700)$ & $0.979(0.331)$ \\
\hline Linearity Test & $1.827(0.178)$ & $2.752(0.056)$ & $2.116(0.164)$ \\
\hline
\end{tabular}

Source: Authors' computation using EViews software

Note: probability values that signify the level of significance are put in parentheses

\section{Conclusion and Policy Recommendations}

This empirical study has been revealing as touching the issue of relationship between financial development and trade in Nigeria. In concise terms, the study shows that financial development is very germane to trade in the long run and that the economy can return to its long run equilibrium in the case there is initial disequilibrium emanated from shocks to the economy. Other variables such as real exchange rate, FDI, real GDP, rest of the world GDP, investment, government consumption spending and so on also play a crucial role in determining the course of trade (export and import).

Based on the findings obtained from this study, the following policy recommendations are proposed:First, the government must provide enabling environment to financial sector to thrive through sound macroeconomic policies that will encourage healthy competition among the major players in the sector. This will encourage di- 
versification of the economy through improved local production.Besides, since it is found in this study that financial development is indispensable to merchandise trade, particularly merchandise export, it is, therefore, become necessary for government to provide a guideline framework for channelling funds to genuine exporters and to make foreign exchange available for importation of additional raw materials that cannot be sourced locally for the local production of competitive goods in the international market. Over-restrictive trade policies that debar trade entrepreneurship should be discouraged to forestall their damning consequences on the economy.

\section{REFERENCES}

Abdullahi, S. A. and Suleiman, H. (2008), An analysis of the determinants of Nigeria's import, Available at http://dx.doi.org/10.2139/ssrn.1232942

Aker, Ş. L., (2008), Major Determinants of Imports in Turkey, Turkish Studies, 9:1, 131-145, DOI: $10.1080 / 14683840701814059$

Beck T. (2002), Financial Development and International Trade: Is there a Link.Journal of International Economics, Volume 57, pp. 107-131.

Beck, T. (2003), Financial Dependence and International Trade.REVIEWS of International Economics, Volume11, pp. 107-131

Beck, T., and R., Levine (2004), Stock Markets, Banks and Growth: Panel Evidence. Journal of Banking and Finance, Volume 28(3), pp. 423-442.

Berman N., (2007), Financial Crises and International Trade: The Long Way to Recovery. University Paris 1.

Boey, T. N., (2010), Determinants of exports in Malaysia, Unpublished Master Thesis, Universiti Sains Malaysia.

Brander James and Paul Krugman, (1983), A Reciprocal Dumping Model of International Trade.Journal of International Economics, Volume 16 (3 - 4), pp. 313 - 321.

Caporale, G. M., C. Rault, R.Sova and A, Sova, Financial Development and Economic Growth: Evidence from Ten New EU Members. Discussion Papers, DutschesInstitut fürWirtschaftsforschung, Berlin Germany.

Central Bank of Nigeria (2014),CBN Statistical Bulletin for the year ended 31st December 2009, Abuja. Central Bank of Nigeria Publication.

Chan, M. L., and K., Manova, (2015), Financial Development and the Choice of Trade Partner.Journal of Development, Volume 116, pp. 122-145

Chinaemerem O. C. and E. E. Chigbu, (2012), An Evaluation of Financial Development and Economic Growth of Nigeria: A Causality Test.Kuwait Chapter of Arabian Journal of Business and Management, Volume 1 (10), pp 29-44.

Demirguc-Kunt, A., M. Cihak, E. Feyen, T. Beck and R.Levin, (2013), Financial Development and Structure Database.The World Bank, Washington, D. C., USA.

Do, Q-T., and A.,Levchenko (2004), Trade and Financial Development. World Bank, Working Paper 3347.

Do, Q-T., and A.Levchenko, (2007), Comparative Advantage, Demand for External Finance, and Financial development.Journal of Financial Economics, Volume 86, pp. 796-834.

Fantessi, A. A., (2015), Financial Development and Economic Growth in Togo.African Journal of Business Management, Volume 9(18), pp 633-640. 
Gerschenkron, A. (1962), Economic Backwardness in Historical Perspective.Cambridge, Mass: Belknap Press of Harvard University Press

Gokemenoglu, K. K., M.Y. Amin and N. Taspinar (2015), The Relationship among International Trade, Financial Development and Economic Growth: The Case of Pakistan.Procedia Economics and Financial, Volume 25, pp. 489-496.

Goldsmith, R. W (1955), Financial Structure and Economic Growth in Advanced Countries.in Abramovitz, M (ed), Capital Formation and EconomicGrowth, Princeton,NJ:Princeton University Press.

Goldsmith, R.W., (1969), Financial Structure and Development.New Haven, Yale University Press

Guiso, L., P. Sapienzaand L.Zingales (2000), The Role of Social Capital in Financial Development. Unpublished Working Paper 7563, NBER, Cambridge, MA

Hur Raj, M. and Y. Riyanto, (2006), Finance and Trade: A Cross-Country Empirical Analysis on the Impact of Financial Development and Assets Tangibility on International Trade, World Development, Volume 34, pp. 1728-1741.

Kehinde J. S., and K. D. Adejuwon, Financial Institutions as Catalyst to Economics Development: the Nigeria Experience.European Journal of Humanities and Social Sciences, Volume 8(1), pp. 323-334

Keindrebeogo Y., (2012), Understanding the Causal Links between Financial Development and International Trade.Universited'Auvergne, CNRS, UMR 6587, CERDI, F-63009 Clermont FD. Email: youssouf.kiendrebeogo@udamail.fr.

King, R. G. and Levine R., (1993), Finance, Entrepreneurship and Growth: Theory and Evidence.Journal of Monetary Economics,Volume 32, pp. 513-42.

King, R.G. and R. Levine (1993), Finance and growth: Schumpeter might be right. Quarterly Journal of Economics, Volume 108, pp. 717-732.

Kletzer, Kenneth and Bardhan, Pranab (1987), Credit Markets and Patterns of International Trade", Journal of Development Economics 27, 57-70.

Leibovici F., (2013), Financial Development and International Trade. York University

Majeed, M. T. and Eatzaz, A., (2009), Determinants of exports in developing countries.The Pakistan Development Review, Vol. 45: 4, pp. 1265-1276.

Mckinnon, R. (1973), "Money and Capital in Economic Development”, Washington D.C: The Brooking Institute

Nkoro, E., and A. Uko (2013), Financial Sector Development-Growth Nexus: Empirical Evidence from Nigeria.American Journal of Contemporary Research, Volume 3 (3), pp. 87-94.

Ogwumike, F. O. and A., A. Salisu, (2010),Financial development and economic growth in Nigeria. Journal of Monetary and Economic Integration, Volume 12(2), pp. 84-89.

Oluitan, R. O., (2012), The Effect of Trade Components of Financial Development in Nigeria. Educational Research, Volume 3(9), pp. 717-722.

Oriavwote, V. E., and S.J.Eshenake (2014),An Empirical Assessment of Financial Sector Development and Economic Growth in Nigeria. International REVIEWS of Management and Business Research, Volume 3(1), pp. 139-145.

Rajan R. G. and L. Zingale (2003), The Great Reversals: The Politics of Financial Development in the Twentieth Cnetury.Journal of Financial Economies, Volume 69, pp. 5-50

Rajan, R. and L., Zingales(1998), Financial Dependence and Growth.American Economic Reviews, 88: 559-86.

Rajan, R., and L., Zingales, (1999),The Politics of Financial Development.Unpublished Working Paper, University of Chicago, Chicago.

Schumpeter, J. A. (1911), The Theory of Economic Development. Camebridge, MA:

Schumpeter, J. A. (1933),The Theory of Economic Development.Translated byRedvers Opie, Cambridge MA: Harvard University Press. 
Schumpeter, J. A., (1912), Theorie der WirtschaftlichenEntwicklung, Leipzig: Dunker \& F Humblot (The Theory of Economic Development) translated by Redvers Opie: Harvard University Press, 1934, MA.

Shahbaz, M., (2009), A Reassessment of Finance-Growth Nexus for Pakistan: Under the Investigation of FMOLS and DOLS Techniques.Journal of Applies Economics, Volume 1, pp. 65-80.

Shaw, E. S. (1973), Financial Deepening in Economic Development.New York: Oxford University Press

Shittu, A. I. (2012), Financial Intermediation and Economic Growth in Nigeria.British Journal of Arts and Social Sciences, ISSN: 2046-9578, Volume 4 (2).

Yee, L. S., WaiMum, H., Zhengyi, T., Ying, L. J. and Xin, K. K., (2016), Determinants of export: empirical study in Malaysia. Journal of International Business and Economics. Vol. 4, No. 1, pp. 61-75. 